This is an Accepted Manuscript of an article published by Taylor \& Francis Group in Journal of Geography in Higher Education on 04/04/16, available online:

http://www.tandfonline.com/10.1080/03098265.2016.1155206. 


\title{
Exploring normative whiteness: ensuring inclusive pedagogic practice in undergraduate fieldwork teaching and learning
}

\author{
Annie Hughes* \\ School of Geography, Geology and the Environment, Kingston University, UK \\ * correspondence to a.hughes@kingston.ac.uk
}

\begin{abstract}
Higher Education commentators have become concerned about how learning and teaching praxis across the sector may unwittingly advantage White British (WB) compared to Black Minority Ethnic (BME) students. Adopting Critical Race Theory, this paper explores these issues in relation to field teaching in Geography and related subjects. It reports on primary data collected from students about to attend their first residential field trip. The research shows that WB and BME students approach their first field trip with diverse geographical experiences. The findings indicate a need to reflect critically on our fieldwork routines in order to promote inclusivity in field learning.
\end{abstract}

\section{Keywords}

Fieldwork, Critical Race Theory, Normative Whiteness, BME (Black and Minority Ethnic), White British, Inclusive Practice 


\section{Introduction}

Over the last ten years, the proportion of UK domiciled Black and Minority Ethnic (BME) students in Higher Education has increased significantly (Equality Challenge Unit, 2012). These trends are echoed in the US context and elsewhere (US Education Department, 2014). This reflects, in part, the widening participation (WP) agenda in Higher Education which aims to encourage individuals from a diverse range of backgrounds into universities motivated by the principle that everyone with the potential to benefit from higher education should have equal opportunity to do so.

Whilst Universities have embraced WP, there is less compelling evidence to suggest that they have taken steps to rethink and reflect on how teaching and learning practices in Higher Education best serve this more diverse student body. Indeed there is significant evidence which indicates that some groups of students are doing significantly less well in universities with resultant attainment gaps. For example, in both the UK and the US, data has consistently shown that home BME students are less likely to achieve a 'good' degree when compared to White students, even where entry qualifications and subjects studied are identical (Broecke and Nicholls, 2007, Fielding, et. al. 2008). Although the complete picture is extraordinary complex, generally UK domiciled BME students do less well in attainment, progression and graduate prospects compared to WB students (Alexander and Arday, 2015). Policies and practices intent on addressing the so-called "BME attainment gap" have begun to emerge and academic disciplines have been charged with reconsidering their curricula and their specific pedagogic activities to better reflect the life-worlds and experiences of all students, including BME students, in order to maximise the attainment of all students.

Using the principles of Critical Race Theory (CRT), this paper considers how the current manifestations of pedagogic practice in Geography and related fields potentially advantage WB students over BME students. CRT like many other forms of critical inquiry began with the recognition of the relationship between knowledge construction and power. Within CRT scholarship, racism is reconceptualised not as the acts of individuals per se, but systemic structures which sustain power through the reproduction of practices which reflect the customs, traditions and praxis of the elite. Although CRT has a relatively short history in education (stemming originally from Critical Legal Studies in the US), its growth and application has been exponential (Taylor, 2009). It argues that the largely White academy is configured around practices which normalise White experience, contributing (often unconsciously) to outcomes that are advantageous to White students.

Specifically, this paper argues that as the educators of an increasingly diverse body of students, academic teachers of Geography and related disciplines in UK HE must question the assumptions they bring to their teaching practice and become more attentive to possibilities of unwitting discrimination based on practices of normative whiteness. The focus of this paper is on the practice of field teaching, more commonly known as fieldwork. Whist not unique to geographical study, fieldwork is a central pillar of geographical learning and teaching at both school and university level (Phillips and Johns, 2012). The importance of fieldwork as constituting an appropriate tool for the development of subject knowledge and skills continues to be accepted (Quality Assurance Agency, 2007, 2014). However there is limited research which explores the differential attitudes to, and experiences of, fieldwork amongst different cohorts of undergraduate students. The research presented in this paper explores the differing experiences of fieldwork of $\mathrm{WB}$ and domiciled BME students. It examines how their perceptions and subsequent experiences of field teaching are mediated through the students' differing backgrounds. Specifically it reports on primary data collected 
with first year students about to attend their first residential field trip at a post-1992 Londonbased University. It explores students' feelings about their imminent trip, examines their pretrip field experiences and their prior knowledge and understanding of the field trip destination. It also assesses their views and reflections on their return from the trip. This work was significant in this particular University given that $53 \%$ of the students are from a BME background and the BME attainment gap is higher than the sector average.

\section{Critical Race Theory and academic practice in Higher Education}

The Higher Education landscape is undoubtedly complex and nuanced. This is the case in the UK, and reflected in other Higher Education sectors in the US and Europe. In the UK, whilst some minority ethnic cohorts outperform WB students, most commentators agree that there is a significant attainment gap between BME and WB students (Equality Challenge Unit, 2012, Alexander and Arday, 2015). A growing body of research has begun to explore the multifaceted reasons for this attainment gap. UK Higher Education Institutions (HEIs) are accused by several commentators of being institutionally racist in the fact that they have consistently failed to provide an appropriate educational experience to people because of their culture, colour or ethnic origin (Gillborn 2008, Pilkington, 2011). Much of this work goes beyond the limiting common-sense conceptualisation of an explicit, intentional and consciously racist education system to embrace a different perspective which promotes racism as an outcome of practices and policies in which whiteness is positioned as normative, and everyone and everything is categorised in relation to it (Gillborn, 2009). This body of work adopts the essence of Critical Race Theory (CRT) which argues that racism is a commonplace facet of life (Delgado, 1995). In terms of education, CRT purports that complex, intricate, and often ensconced, practices are actively implicated in maintaining and extending the educational advantage of white people (Gillborn, 2009). This, it is argued, has acted to disadvantage minority ethnic students in educational structures and amounts to discrimination through unwitting prejudice (Taylor, Gillborn, and Ladson-Billings, 2009).

Commentators have argued that the Higher Education Sector in the UK has been rather slower than other organisations and institutions to address issues of racial disadvantage and discrimination due to its liberal misnomer (Pilkington, 2011). In an overwhelmingly White Academy, colour-blind policies and practices have legitimated institutional habitus which has claimed to represent all but which, in fact, has undermined other ways of learning and teaching. In this way, UK HEIS have, if unintentionally, reproduced racial disadvantage (Pilkington, 2013). In addition, organisational processes and cultural practices which deny racial disadvantage through the conceptualisation of liberalism, fail to prioritise ethnic inequalities and discrimination and the resultant procedures, practices and cultures will maintain the entrenched disadvantages to non-white people. As bell hooks acknowledged in 1989:

"when liberal whites fail to understand how they can and/or do embody whitesupremacist values and beliefs even though they may not embrace racism as prejudice or domination (especially domination that involves coercive control they cannot recognise the ways their actions support and affirm the very structure of racist domination and oppression that they wish to see eradicated". (p. 113) 
New Pedagogic approaches intent on addressing discriminatory practices have begun to emerge. Many are loosely based around the concept of the inclusive curriculum which asserts curriculum design principles developed through student engagement, inclusive learning strategies and the internationalisation of the curriculum (Berry and Loke, 2011, Singh, 2011). Undoubtedly further research must examine how different academic disciplines might act to challenge the practices of normative whiteness embedded within their curricula and interrogate the performity of their pedagogy to maximise the attainment of all students. It is within this frame of reference, that this paper critically evaluates pedagogies of fieldwork.

\section{Critical perspectives on fieldwork}

Fieldwork is intrinsic to teaching and learning in Geography and related disciplines. It's a flexible practice which takes a variety of forms and encompasses a vast array of activities, in a myriad of different places (Gold, et. al, 1991, Saunders, 2011). Over recent years, commentators have begun to evaluate the effectiveness of fieldwork as a pedagogic practice (Fuller et. al, 2006). This exiting research has explored the inherent value of fieldwork and its contribution to geographical education (Herrick, 2010; Stokes et. al. 2011). Essentially fieldwork has been recognised as adding value to teaching and learning in geography on several levels. Perhaps most palpably this is achieved through its principle of experiential learning and learning through 'seeing' and 'doing' (Fuller, et. al, 2000). Fieldwork has also been identified as an important vehicle for acquiring and developing transferable skills such group work, project work and time-management (Haigh \& Gold 1993; Jenkins, 1994; Bradbeer 1996; Kneale 1996); increasing students' employability (Stokes, et.al., 2011) and promoting the acculturation and socialisation of students through reinforcing their cohort identity and engagement, thereby encouraging retention and progression rates (Fuller, et. al., 2006, Hall, et. al. 2002). Welch and Panelli (2003) have also presented some interesting thoughts on the significance of fieldwork in teaching research methodologies (see also Panelli and Welsh, 2005). Furthermore, there is also an increasing body of literature which explores the centrality of fieldwork in developing students understanding of difference (Ling, 2008) and more recently authors have argued that fieldwork offers a rich opportunity to encourage students to engage in critical reflection; questioning their own positionalities (Drummer et. al., 2008, McGuinness and Simm, 2005).

A component of this work has begun to assess the differential value of fieldwork to different cohorts of students. Indeed, in the context of disabled students, Hall et al (2002) point to the need to evaluate the effectiveness of fieldwork for different students to "ensure their full inclusion in the learning experience." (p. 215) Similarly, Dunphy and Spellman (2009) examine students' learning styles and the efficacy of fieldwork and Dalton (2001) explores the significance of students' previous field experiences in their achievements in their HE field setting. Existing work also reflects on the role of gender in the field. Maguire (1998) presents an interesting account of gender differences in attitudes to undergraduate fieldwork whist Boyle et. al. (2007) also examines gender differences as well as social background and age as they mediate field experiences.

Informed by critical epistemologies, more recent work has begun to problematize the relationship between experience and learning, arguing that experience of the 'real world' is never unmediated, straightforward and transparent (Abbott, 2006, Hope 2009). Rather, students' world views necessarily, indeed unescapably, mediate their field experiences 
(Nairn, 2005). For example, Abbott (2006) has called for a critical analysis of what she terms the 'whiteness in fieldwork', arguing for a politicization of the pedagogy of geographical fieldwork. In particular she argues that such a political analysis of fieldwork must recognise its role in reinforcing the overwhelming whiteness of Geography. Critical pedagogical strategies must be pursued which challenge white privilege and in so doing reflect the lifeworlds of students from a diverse range of cultural backgrounds and knowledge systems.

In essence, fieldwork is a situated cultural practice. It is an embodied experience with complex sets of reciprocal relationships at play between individuals and field environments. In this regard, it is crucial that field leaders are aware of, and critically reflect on, the politics of their fieldwork choices. Unwittingly, fieldwork procedures and routines reflect hegemonic socio-cultural relations of sexuality, gender and ethnicity. For example, Nairn (2003) exposes the ways in which domestic arrangements on fieldwork are informed by heteronormative social relations and Eurocentric cultural practices. These implicit practices, she argues, must be unpacked and made explicit before and during fieldwork to create an inclusive learning environment. Moreover, by ignoring the ways in which hegemonic social relations of sexuality, gender and ethnicity inform our teaching spaces and pedagogic practices, we are overlooking "gate-keeping mechanisms" which may be excluding those that do not conform (Nairn, 2003).

\section{Considering field trip destinations as an expression of normative whiteness}

If we accept the arguments that decisions about the procedural aspects of fieldwork draw on practices which are situated within a predominately White academy then it is essential that these processes and procedures are comprehensively (re)considered. Fieldwork destinations in themselves reflect cultural practices and preferences. Notwithstanding the work of McGuiness and Simm (2005) who point to a 'global shift' in undergraduate field work, it remains the case that many UK Higher Education Institutions still frequently (indeed, almost exclusively) travel to domestic UK destinations, particularly in Year 1 (Garside, Hughes and Reid, 2015). Advertised destinations include the Lake District, Cornwall, Devon and the South Coast of England. Decisions about appropriate field destinations are often based on legitimate reasons of cost, staff expertise, risk assessment, travel time and sub-discipline priorities such as geomorphological characteristics. Many of these trips travel to rural environments in the UK, rather than city destinations (see Garside, Hughes and Reid, 2015). Rural fieldwork destinations raise a number of interesting questions with regard to practices of normative whiteness, potentially (and often unwittingly) creating a range of concerns and outcomes for a diverse student body. This is particularly so given the multifaceted, and regularly discriminatory, links between ethnicity and rurality in the UK and beyond which has been identified in academic writings (Agyeman and Spooner, 1997; Neal, 2002, Neal and Agyeman, 2006 Panelli, et. al. 2009). The juxtaposition between the rural as the 'genuine' England as opposed to the multicultural (urban) Britain of the twenty first century has been comprehensively highlighted in the academic literature (Matless, 1998). Whilst not universal, Panelli et. al. (2009) exposes the "profoundly white and Western hegemonies underpinning the construction of many countrysides" (2009, p. 355). In this way, non-White identities are disregarded from rurality, both metaphorically but also in reality as Black and ethnic minority populations fail to identify or engage with rural parts of the UK. Research which identifies the racialisation of the countryside has linked it with the absence of ethnic minorities in rural areas and has been instructive in opening up debates about racism in the countryside (Askins, 2009). Chakraborti and Garland (2004) have assessed the nature and 
extent of racist harassment in rural and isolated areas of Britain and furthermore has gauged the attitudes of white rural residents towards those who are perceived to be 'outsiders'. Whilst in some rural areas, 'outsiders' are constructed in a variety of ways and may include individuals who simply do not originate from the local area, existing work points quite clearly to racist behaviour in the English countryside. This racism takes many forms, ranging from persistent or unnecessary staring and name-calling, through to damage to property and even physical attack (see also Chakraborti and Garland 2006a, 2006b, Dhillon (2006)).

If we are to accept the arguments that rural areas are repositories of white values and lifestyles, juxtaposed with the multicultural ideologies manifest in urban environments, then it would not seem unreasonable to suggest that WB and domiciled BME students may well experience rural environments in rather different ways. In essence, students from various BME cultural backgrounds may well approach, understand and experience rural field destinations quite differently from WB students. This, in turn, may have significant implications for their learning experience and potentially their relative attainment. In this way, field destinations can act to reinforce inequalities between students of different ethnic backgrounds and as a result, there is an imperative on Geography teachers to carefully reflect on and possibly reconsider the implication of their choices on the learning outcomes of all their students.

The remainder of this paper presents the findings of an empirical research project conducted over two years which explored the different understandings and experiences of WB and domiciled BME students as they embarked on their first residential fieldtrip in their first semester of their first year in Higher Education. The research examined students' feelings about their imminent trip, investigated their pre-trip field experiences and their prior knowledge and understanding of the Isle of Wight (the field trip destination). It also assessed their thoughts and reflections on their return from the trip. The research was intended to help inform decisions about the future field programme offered in the School in the light of the changing demographic of our students. It also comprised one component of a wider body of work which focused on developing a more inclusive curriculum where every students' experience and background were fully valued, respected and most importantly reflected in our curriculum content, delivery and assessment. This involved rethinking our curriculum content and our learning and teaching practices to examine how all our students were positioned in a variety of teaching and learning contexts.

\section{Methodology}

The data presented in this paper is part of a survey conducted with Year 1 students studying for a Geography or other Earth and Environmental Science degree in a post-1992 Londonbased University in 2010 and 2011. The University has a significant ethnic mix with $53 \%$ of students coming from a BME background (University Equality, Diversity and Inclusion Annual Report, 2015). Geography and related subjects have not traditionally been popular with BME students (Business in the Community Report, 2010). Nevertheless, the Geographical, Environmental and Earth Sciences subjects have attracted an increasing proportion of students from ethnic minority backgrounds over the last five years. Almost one quarter of the students in this research identified themselves as BME (see Table1). 


\section{Insert table 1}

The trip was a compulsory assessed element for students studying for a range of undergraduate degrees in the GEES (Geography, Earth and Environmental Sciences) subject area, predominately students studying Geography, Human Geography, Geology and Environmental Science. The trip was to the Isle of Wight. As the name suggests, the Isle of Wight is an island located six kilometres off the South Coast of the UK. Its population is almost exclusively from a 'WB' origin, 94.8\% (Isle of Wight Council, 2013). This was the first field experience for these students at HE level. The trip took place in the October of their first year. The students travelled to the Isle of Wight by coach on the Friday morning and stayed in Shanklin for two nights, returning to London on Sunday afternoon. The students undertook a variety of activities on the Island - including studying landslides, ecological management, tourism and impacts of demographic change and migration. Whilst each cohort of students would complete a different combination of exercises, all cohorts were exposed to the physical and socio-economic landscapes of the Isle of Wight and all students had the opportunity to socialise outside the hotel on the Friday and Saturday evenings. Students attended two pre-trip meetings where the relevant risk assessment and health and safety information was disseminated and one post-trip de-brief.

Students completed two questionnaires, one a week before they attended their first field trip to the Isle of Wight and the second one week after their return. The student surveys were implemented during preparatory meetings and feedback sessions run in the field trip module. While attendance at the meetings was compulsory, students' participation in the survey was optional. Despite this, the majority of students took part and completed the questionnaire. The questionnaires were anonymous. The questionnaires included a variety of open and closed questions to allow students to reflect on their feelings. The themes covered in the questionnaire included geographical experience, fieldwork experience, thoughts on their trip to the Isle of Wight and demographic information. A total of 229 questionnaires were completed pre trip and a further 157 were completed post trip (see table 1). For the purposes of this paper students who were identified as non-British (either European or International students) have been excluded and therefore the cohort to be analysed only includes UK domiciled students.

\section{Perceptions and Concerns about Field work Pre Trip}

Similar proportions of BME and WB students reported that they were looking forward to going on the field trip to the Isle of Wight (see table 2). However when asked if they had a choice to go or not to go, would they prefer not to go, 7.8\% of WB students stated that they would prefer not to go compared to $27.7 \%$ of BME students $\left(\chi_{(1)}^{2}=11.862 \mathrm{p}=0.01\right)$.

\section{Insert table 2}

BME students expressed greater concerns and anxiety compared to their WB counterparts in almost all aspects of the trip's organisation prior to travel (see table 3 ). This was the case for the domestic arrangements for the trip. For example, when asked about the accommodation of their culinary requirements whilst on the field trip, $27.9 \%$ of BME students expressed concern compared to $5.5 \%$ of WB students $\left(\chi_{(2)}^{2}=31.974 \mathrm{p}=0.000\right)$. Similarly when asked about religious requirements, $10 \%$ of BME students expressed concern 
compared to $1.8 \%$ of WB students $\left(\chi_{(2)}^{2}=18.272 \mathrm{p}=0.000\right)$. When asked if they were concerned about sharing accommodation with fellow students, 18.3\% of BME students expressed this view compared to only $7.9 \%$ of WB students. This may well reflect the cohorts' different term time living arrangements. WB students were far more likely to be living communally with other students. Whilst $47.9 \%$ of WB students were living with other students in the University's Halls of Residences, only $18.3 \%$ of the BME students identified their living accommodation in this way. Almost $70 \%$ of WB students were involved in some sort of accommodation sharing either in a flat with other students or in a Halls of Residence, whilst only $40 \%$ of BME students shared accommodation with other students.

\section{Insert table 3}

Students were also asked about any concerns that they may have about being away from their families. Again there was a statistically significant difference between the responses from the BME students compared to the WB students. Whilst only $2.4 \%$ of the WB students expressed concern about being away from their family, this rose to $11.7 \%$ amongst the BME students. BME students were significantly more likely to live with their families compared to the WB students. Whilst only $27 \%$ of WB students lived at home or with extended family, $60 \%$ of BME students declared these options as their term time living arrangements. In these terms, there would be an expectation that students living at home would be more concerned and anxious about attending field trips than students who had already moved out of their parental home and were living in communal circumstances with fellow students.

Differing levels of concern between WB and BME students are clearly complex and nuanced. For example, there was no significant difference between BME and WB students with respect to their concerns about the academic work that they had to complete $\left(\chi_{(2)}^{2}=\right.$ $5.713 \mathrm{p}=0.57)$. Concerns and anxieties may be explained by the fact that there are significant differences between the previous fieldwork experienced by these two cohorts during their secondary level schooling. Far fewer BME students had taken part in a field trip as part of their previous geographical studies. Only $66.1 \%$ of BME students had previously attended a field trip, compared to $81.9 \%$ of WB students $\left(\chi_{(1)}^{2}=6.488 \mathrm{p}=0.011\right)$. However of those who did attend a trip at school there is no significant difference between BME and WB students in terms of their enjoyment of their previous experiences. $76.3 \%$ of WB students stated that they enjoyed their previous experiences compared to $72.5 \%$ of BME students.

BME students don't inherently dislike fieldwork. However, with a lack of experience of what field trips entail and concerns about cultural and religious requirements, BME students are understandably more apprehensive than the WB students who have had a greater degree of exposure to this particular teaching praxis. Of the students who had not attended a field trip, almost universally the reason for non-attendance was that the School or College that they had attended had not offered a residential geography field trip as integral to their studies. The lack of experience of attending a field trip not only may have an effect on the levels of anxiety prior to their first trip in Higher Education but it may also affect their academic attainment on the trip. This is because when asked on their return from the Isle of Wight if their previous field experiences on GEES related secondary school programmes were a "good preparation for this trip, over 55\% agreed with a further $25 \%$ indifferent. Furthermore, it is worth noting that the absence of any field experience prior to studying for a undergraduate degree in Higher Education may well have had a significant impact on the 
attainment of students in their secondary learning as $92 \%$ of all students that attended a field trip prior to coming to Higher Education stated that "field trips helped me better understand the subject". In addition, when asked if students had visited the locations of their secondary level field trips prior to their academic trip, $46.2 \%$ of WB students said that they had, whilst only $20 \%$ of BME students had $\left(\left(\chi_{(1)}^{2}=8.780 \mathrm{p}=0.003\right)\right.$. This suggests that secondary school educators should be thinking critically about where they visit for their field experiences to represent the life experiences and knowledge of all their pupils.

A lack of experience of field trips may be one of several reasons why BME students have a greater anxiety before their first field trip. The research also points to the fact that BME students have far less experience of the chosen field trip destination of the Isle of Wight. When asked if students had any concerns as to what the Isle of Wight was like, $19.7 \%$ of BME students expressed concern compared to $3.6 \%$ of WB students $\left(\chi_{(2)}^{2}=23.931\right.$ $\mathrm{p}=0.000$ ). More than $40 \%$ of the WB students had visited the Isle of Wight at least once prior to the field trip, whilst only $30 \%$ of the BME students had visited the Island. Again this is a statistically significant relationship $\left(\chi_{(1)}^{2}=8.780 \mathrm{p}=0.003\right)$. Moreover WB students were more likely to have visited the island multiple times $\left(\chi_{(3)}^{2}=10.989 \mathrm{p}=0.012\right)$ (see table 4).

\section{Insert table 4}

Similarly, BME students are much less likely to report that they have visited "many different parts of the UK". Whilst $47.5 \%$ of WB students agree with this statement, only $23.0 \%$ of BME students agreed. This is a statistically significant relationship $\left(\chi_{(2)}^{2}=, 12.304\right.$ $\mathrm{p}=0.002)$. This difference is also noted when students are asked if they have 'often travelled to the British countryside for holidays or day trips". Whilst $43.0 \%$ of WB students agree with this statement only $19.4 \%$ of BME students did so $\left(\chi_{(2)}^{2}=18.724 \mathrm{p}=0.000\right)$ (see table 5).

\section{Insert table 5}

Examining travel outside the UK, the differences between WB and BME students are less marked and indeed not statistically significant. 47.2\% of WB students reported that they had "travelled outside the United Kingdom more often than within the UK" compared to $52.5 \%$ of BME students $\left(\left(\chi_{(2)}^{2}=, 0578 \mathrm{p}=0.749\right)\right.$. It is also worth noting that a much greater proportion of BME students live in cities and large towns as opposed to small towns and rural areas so will clearly have far less experiential understanding of the nature of small towns and rural areas such as those visited on the field trip to the Isle of Wight (see table 6). In this way, the location of this trip does not reflect the experiences of the BME students with the inevitable consequence that BME students know far less about these types of areas and are less confident travelling to similar places.

Insert Table 6

Expectation meets reality: post field work thoughts 
On their return, BME students are more likely to report that they had enjoyed the trip. $9.2 \%$ of WB students (eleven students) reported that they did not enjoy the trip compared to only one BME students $(2.6 \%)$. The difference is not statistically significant but relevant given the 'turnaround' of opinion from expectation to reality. $50 \%$ of BME students claimed that they had "enjoyed the trip more than I expected" compared to $47.1 \%$ of WB students. Across the Board, there were far fewer significant differences between WB students and BME students on their return from the trip (see table 6). These included differences in responses to the way in which the trip and its location provided for the students cultural, culinary and religious requirements. A significant proportion of both WB and BME were displeased by the quality of the food in the hotel, although quite possibly for different reasons.

The students also seemed to engage well with each other on the trip with $89.2 \%$ of WB students and $81.6 \%$ of BME students agreeing that they "found it easy to fit with the other students". In addition, $95.8 \%$ of WB students and $89.5 \%$ of BME students agreed that they "met some students on the trip that I did not know before". In relation to the academic content of the trip, $76.3 \%$ of the BME students stated that they enjoyed the group work, as did $69.7 \%$ of the WB students. Lastly there was no statistically significant difference between the views of WB and the BME students on the social activities that were provided being appropriate for their cultural beliefs. From the teachers' perspective it is pleasing to note that a high percentage of both BME and WB students felt that they "could approach one of the staff members if I had a problem". This is particularly important given that the academic staff attending the trip were exclusively White, although there was a gender mix.

\section{Insert table 7}

The vast majority of both WB students (90.5\%) and BME $(84.2 \%)$ students felt that the Isle of Wight was an appropriate destination for a field trip. Table 8 presents the responses of both WB and BME students regarding their experiences during their stay in the Isle of Wight. Both cohorts of students similarly felt safe walking around the streets of the Isle of Wight in the day and also at night. Correspondingly, only a very small proportion of both WB and BME students stated that they felt out of place on the Island (see table 7). Interestingly more WB students reported that they felt out of place in the Isle of Wight than BME students with $15.3 \%$ of WB students stating that they felt this way compared to $13.5 \%$ of BME students. The relationship is not statistically significant but is contrary to the expected response. Both cohorts of students felt that the residents on the Island could have been friendlier towards them given that only $67.8 \%$ of WB students and $57.9 \%$ of BME students felt that the residents were friendly toward them. However, there was no statistical significant difference between the two cohorts. Few students expressed an interest in going back to the Isle of Wight with friends and family, although interesting a slightly greater percentage of BME students expressed this desire compared to the WB cohort (see table 8).

\section{Insert table 8}

\section{Discussion}

The research points to the fact that BME students were significantly more concerned and anxious prior to the trip to the Isle of Wight than their WB counterparts. This, it is argued, can be explained by key differences in the cohorts' engagement with their fellow students and 
secondly by their prior geographical knowledge, both academic and personal. Firstly looking at the differing ways in which BME and WB students engage with their student contemporaries, it is clear that BME students are much less likely to live communally with other students at the University, instead remaining at home with their families. Understandably, this could create more anxiety when students are required to attend a residential trip. However, encouragingly, on their return, BME students were more likely to report that they had enjoyed the trip compared to the WB students and more specifically, that they enjoyed the trip more than they had expected. This suggests that fieldwork is an engaging teaching practice enjoyed by all students. However, it points to the need for academic teachers to meticulously prepare students for these trips, addressing worries and anxieties sensitively and comprehensively. Academic staff must possess an awareness of the diverse and complex ways in which contemporary student cohorts engage and interact with their institutions and fellow students, thereby avoiding normative assumptions based on historical manifestations of "the HE experience". Encouragingly the majority of students from both WB and BME backgrounds felt that they engaged well with other students on the trip and stated that they met students that they had not met before. This reflects the great strength of fieldwork to create cohort identity and encourage students from a diverse range of backgrounds to interact (Fuller, et. al., 2006, Hall, et. al. 2002). This may well have an additional significance for BME students who will generally spend less time with fellow students if they live with their families.

The second key difference between $\mathrm{WB}$ and BME students was in their prior knowledge. Firstly far fewer BME students had taken part in a field trip as part of their previous geographical studies. Reasonably, this would make BME students more apprehensive than the WB students who had a greater degree of exposure to this particular method of teaching. Furthermore, it may also place BME students in a disadvantageous position. This is because this lack of experience of field teaching may affect their academic attainment on the trip given that students who had previously attended a field trip felt that their prior experience was a good preparation for their first trip in Higher Education. Given this, academic teachers should consider ensuring that the first field trip assessment is wholly formative, rather than summative, to better promote a level playing field amongst all students.

The second fundamental difference in terms of prior knowledge relates to the fact that BME students had less direct experience with the type of geographical area represented by the fieldtrip destination, nor indeed the field location itself. This reflects the work of Panelli and others who argue that rural areas, of which the field destination was one, are essentially repositories of white values and lifestyles, which fail to 'speak to' BME identities and experiences. There is clearly potential here for the creation an inequitable starting position, particularly in a Human Geography project where BME students may well have a limited understanding of the socio-cultural customs and practices of small towns and rural communities. The message here is that academic teachers must be mindful of, and possibly (re)consider, field destinations in relation to their cohorts' prior experiences.

Encouragingly, the participant students did not experience the more extreme forms of racism during the field trip documented in the work of Chakraborti and Garland (2004) and Dhillon (2006). Both our BME and WB students felt similarly safe walking around the streets of the Isle of Wight in the day and also at night. Correspondingly, only a very small proportion of both $\mathrm{WB}$ and BME students stated that they felt out of place on the Island. However, it is noteworthy that a much larger proportion of BME students felt that they were ill-prepared for how different the Island was "to home", although interestingly more WB students reported that they felt 'out of place' in the Isle of Wight compared to their BME 
counterparts. It is incumbent on field leaders to adequately prepare their students their field destinations, acknowledging that different cohorts may have differing needs and experiences.

\section{Conclusion}

Although this article has focused on field teaching practices, the research has wider implications for the ways in which academic teachers in Geography and the HE sector more widely, should be responding to the increasingly number of 'non-traditional' students in the sector. Whilst Universities have embraced widening participation, there is less compelling evidence that the sector has taken adequate steps to rethink and reflect on how its teaching and learning practices best serve our modern diverse student body. The purpose of this research was to ask some pertinent questions about the differential experiences of fieldwork amongst our diverse body of students paying particular attention to ethnicity. In so doing, the teaching team would be able to identify and address, if necessary, any normative practices identified by students as being discriminatory. The research showed that there were clear and unequivocal differences in the prior geographical experiences and knowledge of the WB students compared to the domiciled BME students. The BME students were far less likely to have taken part in a field trip as part of their previous geographical studies and secondly BME students had less direct experience with the type of geographical area represented by the fieldtrip destination (nor indeed the field location itself). In addition, it was clear that the BME students had chosen (or had been forced) to 'do university differently' by staying at home whilst studying at University, rather than following the more traditional model of leaving the parental home and living with student contemporaries. These factors, amongst others, may have been responsible for the deepened concern and anxiety recorded by the BME students prior to travel. The research has highlighted that common expectations amongst HE academics which assume that all students know what fieldwork is, have attended a field trip prior to coming to study at a Higher Education Institution and are experienced in living away from home and away from their familial setting are, in fact, normative and do not reflect the situated practice of a large number of students; often but not exclusively based on their ethnicity. In so doing, the research reflects the fact that current manifestations of field practice in Geography and related fields may advantage students that are more likely to reflect traditional ways of 'doing University'. This advantage is subtle and unintentional; but may result in an outcome which unwitting favours one group of students over another and which therefore sets an unfair starting point.

Significantly, however, this piece of work showed that on their return, BME students were more likely to report that they had enjoyed the trip compared to the WB students and more specifically, that they enjoyed the trip more than they had anticipated. This was an unexpected, but immensely pleasing finding for the teaching team. It showed that whilst our BME students were indeed more wary of the pedagogic practice of field teaching, something had 'gone right' in that we had not alienated our BME students further with our practice and procedures on the trip itself and that the fieldwork was perceived as an engaging teaching practice enjoyed by most of the students. It is unclear as to why the students felt more positive on their return. Qualitative commentary suggests that because it was a trip relatively early on in the academic cycle, the BME students living at home had not, prior to the trip, had the chance to build solid friendships. The trip provided the time and space for the students to consolidate friendships with what several students referred to as 'like-minded people'. This was reported as an unexpected bonus on their return and reflects the great strength of fieldwork to create cohort identity and encourage students from a diverse range of 
backgrounds to interact (Fuller, et. al., 2006, Hall, et. al. 2002). In addition, the hotel which accommodated our party was described by several students 'as out of the 1970s' - in terms of the décor, food and service. Many students, both WB and BME, felt that the hotel fell significantly short in catering for their needs irrespective of cultural preference. Moreover, many of the students, most of whom hailed from the Capital, were quite shocked by the 'backwardness' of Shanklin, with its dearth of globalised fast-food outlets and international coffee shops. This perception seemed to unite the students as sophisticated urbanites, and acted to diminish differences within the student group.

The field team were undoubtedly pleased with the reported comments of students on their return. Most staff attending the trip were already cognisant of appropriate culture sensitivities; particularly around issues related to alcohol, halal and (religious and cultural) gendered sensitivities. The very fact that this research was being carried out reflects the sensitivity of the teaching team to potential practices that may have alienated some of our students and many were anecdotally aware that students approach their first trip with a diverse set of experiences and anxieties. As academic teachers with a duty of care to all our students, we must address these sensitively and comprehensively; before, during and after our field visits.

In essence, fieldwork, as all our teaching and learning practices is culturally situated. The field experience is an embodied one, involving complex sets of reciprocal relationships between university structures, departmental norms, academic practices and field environments. All UK HEI's offering education in geographical and earth sciences should be encouraged to reflect on their fieldwork routines in order to promote inclusivity and equality in field learning and to maximise attainment for all students from all backgrounds. In the preparation and execution of fieldwork, attention should be paid to ethnic and cultural difference, and field trip destinations considered with these intentions in mind. Undoubtedly further research must engage with these complex debates to challenge any potentially discriminatory practices which lurk within our curricula and our pedagogic practice. Finally, it is important to recognise that there are significant and incredibly nuanced socio-cultural and economic differences within the categories of WB or BME. Intersectionality brings with it the challenge of understanding the multiple and interlinked dimensions of discrimination based not only on ethnicity, but also gender, religion and socio-economic status. Clearly there is a need to take a more qualitative perspective in future research to tease out some of the more complex relationships as they relate to multi dimensions of inequality and difference. However, the intention of this research is to move the debate on and promote the on-going process of critical self-reflection in an attempt to ensure truly inclusive and equitable pedagogies and inclusive curricula. We live in a dynamic world, and our increasingly diverse student body is a positive outcome of globalisation and increased geographical and social mobility. Education should fully embrace diversity, difference and inclusion and our educational practices should be open, responsive and respectful to this diversity. Fieldwork is the most fantastic way of introducing students to the world's complexities so let's approach it in the most inclusive way possible - by critically reflecting on and addressing, the politics of our fieldwork routines and practices.

\section{Acknowledgements}

A debt of gratitude is also owed to the students who completed the questionnaires and gave up their time to discuss their field experiences. Thank you to Dr Annabelle Boulay who 
conducted some of the data collection and initial analysis for this project. Thank you also to two insightful referees whose comments strengthened the key messages in the paper. This work was financially supported by the Geography, Earth and Environmental Subject Centre.

\section{References}

Abbott, D. (2006) Disrupting the "whiteness of fieldwork in Geography. Singapore Journal of Tropical Geography, 27, 326-341. Doi: 10.1111/j.1467-9493.2006.00265

Askins, K. (2009) Crossing divides: Ethnicity and rurality. Journal of Rural Studies 25 365375. doi:10.1016/j.jrurstud.2009.05.009.

Agyeman, J. and Spooner, R., 1997. Ethnicity and the rural environment. In: P. Cloke, and J. Little, (Eds.), Contested Countryside Cultures (pp. 197-217). London: Routledge.

Alexander, C. and Arday, J. (2015) Aiming Higher: Race, inequality and diversity in the Academy, London: Runnymede Trust. Retrieved from http://www.runnymedetrust.org/docs/search.html?cx=002282106998934022291\%3A9g52mk suzv4\&cof=FORID\%3A11\&q=academy

Berry, J. and Loke, G. (2011), Improving the degree attainment of Black and minority ethnic students, ECU/HEA. $\quad$ Retrieved from http://www.heacademy.ac.uk/assets/documents/inclusion/ethnicity/ImprovingDegreeAttainm ent.pdf link to open resource.

Boyle A, Maguire S, Martin A, Milsom C, Nash R, Rawlinson S, Turner A, Wurthman, S. and Conchie, S. (2007) Fieldwork is good: the student perception and the affective domain. Journal of Geography in Higher Education 31, 299-317. doi: 10.1080/03098260601063628

Bradbeer, J. (1996) Problem-based learning and fieldwork: a better method of preparation. Journal of Geography in Higher Education, 20, 11-18.

Broecke, S. and Nicholls, T. (2007) Ethnicity and Degree Attainment, DfES Research Report W92. Retrieved at: http://webarchive.nationalarchives.gov.uk/20130401151715/http://www.education.gov.uk/pu blications/eOrderingDownload/RW92.pdf

Business in the Community (2010) Race into Higher Education: Today's diverse generation into tomorrow's workforce. Retrieved at http://raceforopportunity.bitc.org.uk/researchinsight/research-articles/1race-higher-education-2the-race-work

Chakraborti, N. and Garland, J. (Eds.) (2004) Rural Racism, Cullompton: Willan.

Dalton, R. (2001) What do they bring with them? the fieldwork experiences of undergraduates on entry into higher education. Journal of Geography in Higher Education, 25, 379-393. Doi: 10.1080/03098260120067673

Delgado, R. (1995) (Ed.) Critical race theory: the cutting edge. Philadelphia: Temple University Press.

Dhillon P. (2006) Challenging rural racism. London: NCVO Publications. 
Drummer, T., Cook, I., Parker, S. Barrett, G. and Hull, A. (2008) Promoting and assessing 'deep learning' in Geography field work: an evaluation of reflective field diaries. Journal of Geography in Higher Education, 32, 459-479. doi:10.1080/03098260701728484

Dunphy, A. and Spellman, G. (2009) Geography, fieldwork value and learning styles. International Research in Geographical and Environmental Education, 18, 19-28. Doi: $10.1080 / 10382040802591522$

Equality Challenge Unit (2012) Equality in higher education: statistical report 2012 Retrieved from http://www.ecu.ac.uk/publications/equality-in-he-stats-2012/.

Fielding, A., Charlton, C., Kounali, D. and Leckie, G. (2008) Degree attainment, ethnicity and gender: interactions and the modification of effects - a quantitative analysis. York: Higher Education Academy. Retrieved from: www.heacademy.ac.uk/resources/detail/ourwork/inclusion/EDA_quantitative_report

Fuller, I., Edmondson, S., France, D., Higgitt, D. and Ratinen, I. (2006) International perspectives on the effectiveness of geography fieldwork for learning. Journal of Geography in Higher Education, 30, 89-101. doi: 10.1080/03098260500499667

Fuller, I, Rawlinson, S. and Bevan, R. (2000) Evaluation of student learning experience in physical geography field work: paddling or pedagogy? Journal of Geography in Higher Education, 24, 199-215. Retrieved from http://114.255.218.96/research/English/evaluation\%20physical\%20geography\%20fieldwork. $\underline{\mathrm{pdf}}$

Garland, J. and Chakraborti, N. (2006a) Recognising and responding to victims of rural racism. International Review of Victimology, 1, 49-69. doi: 10.1177/026975800601300103

Garland, J. and Chakraborti, N. (2006b) Race, place and space: examining identity and cultures of exclusion in Rural England. Ethnicities, 2, 159-177.

Garside, P. Hughes, A. and Reid, A. 2015 The Place of Fieldwork in Geography Undergraduate Programmes in UK HEIs, Research Report, Nuffield Foundation.

Gillborn, D. (2009) Education policy as an act of supremacy: whiteness, critical race theory and education reform. In E. Taylor, D. Gillborn and G. Ladson-Billings (Eds.) Foundations of Critical Race Theory in Education (pp 51- 69). New York: Routledge.

Gillborn, D. (2008) Racism and education: coincidence or conspiracy. Abingdon: Routledge.

Gold, J.R., Jenkins, A., Lee, R., Monk, J., Riley, J., Sheppard, I. D. H. and Unwin, D. J. (1991) Teaching Geography in Higher Education, Oxford: Blackwell.

Haigh, M. and Gold, J. (1993) The problems with fieldwork: a group-based approach towards integrating fieldwork into the undergraduate geography curriculum. Journal of Geography in Higher Education, 17, 21-32.

Hall, T., Healey, M. and Harrison, M. (2002) Fieldwork and disabled students: discourses of exclusion and inclusion. Transactions of the Institute of British Geographers NS, 27, 213231.

Herrick, C. (2010) Lost in the field: ensuring student learning in the 'threatened' geography fieldtrip. Area, 42, 108-116. doi: 10.1111/j.1475-4762.2009.00892 
hooks, b. (1989) Talking back: thinking feminist. Thinking black, Boston: South End Press.

Hope, M. (2009) The importance of direct experience: a philosophical defence of fieldwork in human geography. Journal of Geography in Higher Education, 33, 169-182. Doi:10.1080/03098260802276698

Jenkins, A. (1994) Thirteen ways of doing fieldwork with large classes/more students, Journal of Geography in Higher Education. 18, 43-154. Retrieved from http://www.jiscjournalarchives.ac.uk/openurl.html?ref=tf/cjgh20_cjgh20.v018.i02_20110830 163006_507866/cjgh20.v018.i02/03098269408709250/03098269408709250.pdf

University (2014) Equality, Diversity and Inclusion Annual Report, 2015, Retrieved form http://cdn.kingston.ac.uk/documents/aboutkingstonuniversity/equality-diversity-andinclusion/documents/equality-annual-report-2015.pdf

Kneale, P. (1996) Organising student-centred group fieldwork and presentations. Journal of Geography in Higher Education, 20, 65-74.

Ling, O. G. (2008) Where are the buses?' - role of Geography fieldwork in a socially fragmented world. The Asia-Pacific Education Researcher, 17, 33-41. Retrieved from http:// xsite.dlsu.edu.ph/research/journals/taper/pdf/200808/3Ooi.pdf.

Maguire, S. (1998) Gender differences in attitudes to undergraduate fieldwork, Area, 30, 225235. Retrieved from http://onlinelibrary.wiley.com/doi/10.1111/j.1475$\underline{\text { 4762.1998.tb00065.x/pdf }}$

Matless, D., 1998. Landscape and Englishness., London: Reaktion Books.

McGuiness, M. and Simm, D. (2005) Going global? long haul fieldwork in undergraduate geography. Journal of Geography in Higher Education 29, 241-253. Doi:10/1080/03098260500130478

Nairn, K. (2003) What has the geography of sleeping arrangement s got to do with the geography of your teaching spaces? Gender, Place and Culture, 24, 67-81. Doi:10.1080/0966369032000052667.

Nairn, K. (2005) The problems of utilising 'direct experience' in geography education. Journal of Geography in Higher Education, 29, 293-309. DOI:10.1080/03098260500130635

Neal, S.,( 2002) Rural landscapes, representations and racism: examining multicultural citizenship and policy-making in the English countryside. Ethnic and Racial Studies 25, 442461.

Neal, S. and Agyeman, J. (Eds.) (2006). The new countryside?: ethnicity, nation and exclusion in Contemporary Rural Britain. London: Policy Press.

Panelli, R., Hubbard, P., Coombes, B. and Suchet-Pearson, S. (2009) De-centring White ruralities: Ethnic diversity, racialisation and Indigenous countrysides. Journal of Rural Studies, 25, 355-444. doi:10.1016/j.jrurstud.2009.05.002

Panelli, R. and Welch, R. (2005) Teaching research through field studies: a accumulative opportunity for teaching methodology to human geography undergraduates. Journal of Geography in Higher Education, 29, 255-277. doi: 10.1080/03098260500130494 
Pilkington, A. (2013) How appropriate is it to characterise Western universities as institutionally racist? International Journal of Interdisciplinary Global studies, 7, 2, 13-25. Retrieved from http://nectar.northampton.ac.uk/5650/3/Pilkington20135650.pdf

Pilkington, A. (2011) Institutional racism in the Academy, Trentham Books.

Phillips, C. (2011) Institutional racism and ethnic inequalities: An expanded multilevel framework, Journal of Social Policy, 40, 173-192. Doi:10.1017/S0047279410000565.

Phillips, R. and Johns, J. (2012) Fieldwork for human Geography. London: Sage.

Quality Assurance Agency for Higher Education (2014) Bench marking statement Geography, Quality Assurance Agency for Higher Education 2007. Retrieved from http://www.qaa.ac.uk/publications/informationandguidance/publication?PubID=540\#.VTfhBBxwZjo

Quality Assurance Agency for Higher Education (2007) Bench marking Statement - Earth sciences, environmental sciences and environmental studies; Quality Assurance Agency for Higher Education 2007. Retrieved from http://www.qaa.ac.uk/en/Publications/Documents/Subject-benchmark-statement-Earthsciences-environmental-sciences-and-environmental-studies.pdf

Saunders, A. (2011) Exhibiting the field for learning: telling New York's stories. Journal of Geography in Higher Education, 35, 185-197. Doi:10.10080/03098265.2010.524195.

Singh, G. (2011), Black and minority ethnic (BME) students' participation in higher education: improving retention and success, A synthesis of research evidence. Retrieved from https://www.heacademy.ac.uk/resources/detail/inclusion/Ethnicity/BME_synthesis

Stokes, A., Magnier, K. and Weaver, R. (2011) What is the use of fieldwork? conceptions of students and staff in Geography and Geology. Journal of Geography in Higher Education, 35, 121-141. doi:10.1080/03098265.2010.487203

Taylor, E. (2009) The Foundations of Critical Race Theory in Education: an introduction, In E. Taylor, D. Gillborn and G. Ladson-Billings (Eds.) Foundations of Critical Race Theory in Education (pp 51-69). New York: Routledge.

US Department for Education (2014) Projections of Education Statistics to 2022 (Forty-first Edition). Retrieved from http://nces.ed.gov/pubs2014/2014051.pdf

Welch, R. and Panelli, R. (2003) Teaching research methodology to geography undergraduates: rationale and practice in a human geography programme. Journal of Geography in Higher Education, 27, 255-277. doi: 10.1080/030982260500130494.

Table 1: Sample Characteristics

\begin{tabular}{|l|l|l|l|}
\hline & & Pre Trip & Post Trip \\
\hline Year of Completion & 2010 & 122 & 77 \\
\hline Year of Completion & 2011 & 107 & 80 \\
\hline Total number of respondents & 2010 and 2011 & 229 & 157 \\
\hline Ethnicity & BME & $62(27.2 \%)$ & $38(24.2 \%)$ \\
\hline Ethnicity & WB & $166(72.8 \%$ & $119(75.8 \%$ \\
\hline Missing Data & & 1 & 0 \\
\hline
\end{tabular}


Source: Survey

Table 2: Students' Anticipation of the Trip

\begin{tabular}{|l|r|r|}
\hline \% Agree & WB & BME \\
\hline $\begin{array}{l}\text { I am really looking forward to attending } \\
\text { the Isle of Wight trip. }\end{array}$ & $142(89.3 \%)$ & $50(89.3 \%)$ \\
\hline $\begin{array}{l}\text { I would rather not go on the field trip if I } \\
\text { had a choice }\end{array}$ & $10(7.8 \%)$ & $13(27.7 \%)$ \\
\hline
\end{tabular}

Source: Survey

Table 3: Students' Concerns Pre Trip

\begin{tabular}{|c|c|c|}
\hline I am concerned about what the Isle of Wight is like & WB & BME \\
\hline Not concerned & $135(81.8 \%)$ & $32(52.5 \%)$ \\
\hline Indifferent & $24(14.5 \%)$ & $17(27.9 \%)$ \\
\hline \multirow[t]{3}{*}{ Concerned } & $6(3.6 \%)$ & $12(19.7 \%)$ \\
\hline & 165 & 61 \\
\hline & & $\mathrm{p}=.000$ \\
\hline $\begin{array}{l}\text { I am concerned about sharing accommodation with } \\
\text { my fellow students }\end{array}$ & WB & BME \\
\hline Not concerned & $130(78.8 \%)$ & $40(66.7 \%)$ \\
\hline Indifferent & $22(13.3 \%)$ & $9(15.0 \%)$ \\
\hline \multirow[t]{3}{*}{ Concerned } & $13(7.9 \%)$ & $11(18.3 \%)$ \\
\hline & 165 & 60 \\
\hline & & $p=.065$ \\
\hline $\begin{array}{l}\text { I am concerned about the food accommodating my } \\
\text { cultural requirements }\end{array}$ & WB & BME \\
\hline Not concerned & $147(89.1 \%)$ & $34(55.7 \%)$ \\
\hline Indifferent & $9(5.5 \%)$ & $10(16.4 \%)$ \\
\hline \multirow[t]{3}{*}{ Concerned } & $9(5.5 \%)$ & $17(27.9 \%)$ \\
\hline & 165 & 61 \\
\hline & & $\mathbf{P}=.000$ \\
\hline $\begin{array}{l}\text { I am concerned about the trip accommodating my } \\
\text { religious requirements }\end{array}$ & WB & BME \\
\hline Not concerned & $160(97.6 \%)$ & $49(81.7 \%)$ \\
\hline Indifferent & $1(0.6 \%)$ & $5(8.3 \%)$ \\
\hline \multirow[t]{3}{*}{ Concerned } & $3(1.8 \%)$ & $6(10.0 \%)$ \\
\hline & 164 & 60 \\
\hline & & $p=.000$ \\
\hline I am concerned about being away from family & WB & BME \\
\hline Not concerned & $153(92.7 \%)$ & $45(75 \%)$ \\
\hline Indifferent & $8(4.8 \%)$ & $8(13.3 \%)$ \\
\hline \multirow[t]{3}{*}{ Concerned } & $4(2.4 \%)$ & $7(11.7 \%)$ \\
\hline & 165 & 60 \\
\hline & & $P=.001$ \\
\hline I am concerned about family disapproval about & WB & BME \\
\hline
\end{tabular}




\begin{tabular}{|l|r|r|}
\hline attending the trip & & \\
\hline Not concerned & $163(98.8 \%)$ & $58(95.1 \%)$ \\
\hline Indifferent & $1(0.6 \%)$ & $1(1.6 \%)$ \\
\hline Concerned & $1(0.6 \%)$ & $2(3.3 \%)$ \\
\hline & 165 & 60 \\
\hline & $\mathbf{W B}$ & $\mathbf{p = . 2 2 4}$ \\
\hline $\begin{array}{l}\text { I am concerned about the academic work that we } \\
\text { have to complete. }\end{array}$ & $56(33.9 \%)$ & $12(19.7 \%)$ \\
\hline Not concerned & $46(27.9 \%)$ & $16(26.2 \%)$ \\
\hline Indifferent & $63(38.2 \%)$ & $33(54.1 \%)$ \\
\hline Concerned & 165 & 61 \\
\hline & & $\mathbf{p = . 0 5 7}$ \\
\hline
\end{tabular}

Table 4 The number of times that students had visited the Isle of Wight prior to their field trip

\begin{tabular}{|l|r|r|}
\hline Number of times you have visited the isle of Wight & & \\
\hline & WB & BME \\
\hline Never & $50(30.1 \%)$ & $25(41.0 \%)$ \\
\hline Once & $68(41.0 \%)$ & $30(49.2 \%)$ \\
\hline Twice & $20(12 \%)$ & $5(8.2 \%)$ \\
\hline Three times or more & $28(16.9 \%)$ & $1(1.6 \%)$ \\
\hline & & $\mathrm{p}=0.012$ \\
\hline
\end{tabular}

Source: Survey

Table 5: Students' experiences of travelling in the UK

\begin{tabular}{|l|r|r|}
\hline I have visited many different parts of Britain & WB & \multicolumn{1}{l|}{ BME } \\
\hline Disagree & $42(26.3 \%)$ & $28(45.9 \%)$ \\
\hline Neither agree nor disagree & $42(26.3 \%)$ & $19(31.1 \%)$ \\
\hline Agree & $76(47.5 \%)$ & $14(23.0 \%)$ \\
\hline Total & & 61 \\
\hline & & $\mathrm{p}=0.002$ \\
\hline $\begin{array}{l}\text { I have often travelled to the British countryside } \\
\text { for holidays or day trips }\end{array}$ & WB & \multicolumn{1}{|c|}{ BME } \\
\hline & $50(31.6 \%)$ & $39(62.9 \%)$ \\
\hline Disagree & $40(25.3 \%)$ & $11(17.7 \%)$ \\
\hline Neither agree nor disagree & $68(43.0 \%)$ & $12(19.4 \%)$ \\
\hline Agree & & 62 \\
\hline Total & & $\mathrm{p}=0.000$ \\
\hline & & \\
\hline I have travelled outside the United Kingdom more & & \\
\hline
\end{tabular}




\begin{tabular}{|l|r|r|}
\hline often than within the UK & & WB \\
\hline Disagree & $49(30.8 \%)$ & $16(26.2 \%)$ \\
\hline Neither agree nor disagree & $35(22.0 \%)$ & $13(21.3 \%)$ \\
\hline Agree & $75(47.2 \%)$ & $32(52.5 \%)$ \\
\hline Total & 159 & 61 \\
\hline & & $\mathrm{p}=0.749$ \\
\hline
\end{tabular}

Source: Survey

Table 6: Type of area that students had grown up in

\begin{tabular}{|l|r|r|}
\hline Type of Area that students had grown up in & WB & \multicolumn{1}{|l|}{ BME } \\
\hline City/Large Town & $79(51.0 \%)$ & $47(79.7 \%)$ \\
\hline Small Town & $36(23.2 \%)$ & $6(10.2 \%)$ \\
\hline Rural/Countryside/Seaside & $40(25.8 \%)$ & $6(10.2 \%)$ \\
\hline & 155 & 59 \\
\hline & & $\mathrm{P}=0.001$ \\
\hline
\end{tabular}

Source: Survey

Table 7 Students' views post-trip

\begin{tabular}{|c|c|c|}
\hline & \multicolumn{2}{|c|}{ \% Agree } \\
\hline & WB & BME \\
\hline \multirow{2}{*}{$\begin{array}{l}\text { The food in the hotel accommodated my cultural } \\
\text { needs }\end{array}$} & $71(59.7 \%)$ & $16(42.1 \%)$ \\
\hline & & $\mathrm{P}=0.050$ \\
\hline \multirow[t]{2}{*}{ The trip accommodated my religious requirements } & $58(50 \%)$ & $17(44.7 \%)$ \\
\hline & & $\mathrm{p}=0.802$ \\
\hline \multirow{2}{*}{$\begin{array}{l}\text { I felt that I could approach one of the staff members if } \\
\text { I had a problem }\end{array}$} & $98(82.4 \%)$ & $31(81.6 \%)$ \\
\hline & & $\mathrm{p}=0.819$ \\
\hline \multirow{2}{*}{$\begin{array}{l}\text { My experiences on the trip have reassured me about } \\
\text { subsequent course trips }\end{array}$} & $83(69.7 \%)$ & $23(62.2 \%)$ \\
\hline & & $\mathrm{p}=0.266$ \\
\hline \multirow[t]{2}{*}{ I found it easy to fit with the other students } & $106(89.2 \%)$ & $31(81.6 \%)$ \\
\hline & & $\mathrm{p}=0.187$ \\
\hline \multirow{2}{*}{$\begin{array}{l}\text { I met some students on the trip that I did not know } \\
\text { before }\end{array}$} & $114(95.8 \%)$ & $34(89.5 \%)$ \\
\hline & & $\mathrm{p}=0.337$ \\
\hline \multirow{2}{*}{$\begin{array}{l}\text { My family were worried about me when I was away } \\
\text { on the trip }\end{array}$} & $5(4.2 \%)$ & $4(10.5 \%)$ \\
\hline & & $\mathrm{p}=0.061$ \\
\hline \multirow{2}{*}{$\begin{array}{l}\text { The social activities were appropriate for my cultural } \\
\text { beliefs }\end{array}$} & $72(61.0 \%)$ & $25(65.8 \%)$ \\
\hline & & $p=0.662$ \\
\hline \multirow[t]{2}{*}{ The physical assertion was less than anticipated } & $66(55.5 \%)$ & $16(44.4 \%)$ \\
\hline & & $\mathrm{p}=0.160$ \\
\hline I enjoyed the group work & $83(69.7 \%)$ & $29(76.3 \%)$ \\
\hline
\end{tabular}


Source: Survey

Table 8 Students' Experiences during the trip.

\begin{tabular}{|l|r|r|}
\hline & \multicolumn{2}{|c|}{ \% Agree } \\
\hline $\begin{array}{l}\text { I felt safe walking around the streets on the Isle of } \\
\text { Wight during the day }\end{array}$ & $114(96.6 \%)$ & $35(92.1 \%)$ \\
\hline & & $\mathrm{p}=0.245$ \\
\hline $\begin{array}{l}\text { I feel safe walking around the streets on the Isle of } \\
\text { Wight when it was dark. }\end{array}$ & $103(87.3 \%)$ & $31(81.6 \%)$ \\
\hline & $80(67.8 \%)$ & $22(57.9 \%)$ \\
\hline $\begin{array}{l}\text { I found the residents on the Island were friendly } \\
\text { towards me. }\end{array}$ & $44(37.3 \%)$ & $16(42.1 \%)$ \\
\hline $\begin{array}{l}\text { I would go back to the Isle of Wight with friends and } \\
\text { family in the future. }\end{array}$ & & $\mathrm{p}=0.714$ \\
\hline & $18(15.3 \%)$ & $5(13.5 \%)$ \\
\hline I felt 'out of place' on the Isle of Wight & $15(12.7 \%)$ & $6(16.7 \%)$ \\
\hline & & $\mathrm{p}=0.814$ \\
\hline I would never go back to the Isle of Wight & $7(5.9 \%)$ & $6(16.2 \%)$ \\
\hline & & $\mathrm{p}=0.172$ \\
\hline $\begin{array}{l}\text { I was not prepared for how different the Island was to } \\
\text { home. }\end{array}$ & & \\
\hline
\end{tabular}

Source: Survey 